\title{
Hakikat Nilai Hormat dan Tanggung Jawab Thomas Lickona dalam Perspektif Islam (Sebuah Pendekatan Integratif- Intorkonektif)
}

\author{
Fathurrahman \\ UIN Sunan Kalijaga Yogyakarta \\ Email: fathurr587@gmail.com
}

\begin{abstract}
This article aims to analyze Thomas Lickona's perspective that presents a new paradigm in the discussion of character education, especially related to respect and responsibility. The method of library research with the integration-interconnection approach was applied in this study, in order to present a comprehensive perspective of Thomas Lickona associated with the Islamic doctrine. The application of integrationinterconnection approaches in this study is intended not to identify or criticize but rather to present arguments that corroborate each other's. In this study showed that embryos of Thomas Lickona's idea of respect and responsibility that became a major part of character education were built on the moral tendencies that are the benchmark of human behavior, where meaningful respect demonstrates good behavior towards one self, others, and the environment. While the responsibility is to respond and respect every burden entrusted. The meeting point of this openion with the values of Islamic doctrine is the preesing on the importance of being respectful in every dimension of human life. Respect in Islam means a tribute to one self, others, and the environment. So that every human action and treatment is limited to himself, others, and the environment becomes his responsibility both personally, vertically (to God), and horizontally (to others). Based on that view, man must position himself as Caliph (leader), Abdullah (servant), and part of society in ensuring a better life.
\end{abstract}

Keyword: integrative-interconective, respect, responsibility. 


\begin{abstract}
Abstrak
Artikel ini bertujuan untuk menganalisis perspektif Thomas Lickona yang menghadirkan paradigma baru dalam perbicangan tentang pendidikan karakter, khususnya berkaitan dengan sikap hormat dan tanggung jawab. Metode studi pustaka dengan pendekatan integrasiinterkoneksi diterapkan dalam penelitian ini, supaya menghadirkan suatu pandang yang komprehensif dalam melihat perspektif Thomas Lickona yang dikaitkan dengan ajaran-ajaran Islam. Aplikasi pendekatan integrasi-interkoneksi dalam penelitian ini dimaksudkan bukan untuk menjudtifikasi atau mengkritisi melainkan untuk menghadirkan argumentasi yang saling menguatkan antara pandangan yang satu dengan lainnya. Hasil penelitian ini menunjukkan bahwa embrio dari gagasan Thomas Lickona tentang hormat dan tanggung jawab yang menjadi bagian utama dalam pendidikan karakter dibangun atas dasar tendensi moral yang menjadi tolak ukur perilaku manusia, dimana hormat bermakna menunjukkan perilaku yang baik terhadap diri, orang lain, dan lingkungan. Sedangkan bertanggung jawab adalah merespon dan menghormati setiap beban yang dipercayakan. Titik temu pandangan tersebut dengan nilai-nilai ajaran Islam adalah penekanannya terhadap pentingnya bersikap hormat dalam setiap dimensi kehidupan manusia. Hormat dalam Islam bermakna sebuah penghargaan terhadap diri sendiri, orang lain, dan lingkungan. Sehingga setiap tindakan dan perlakuan manusia terhadp dirinya, orang lain, dan lingkungan menjadi tanggung jawabnya baik secara personal (pribadi), vertikal (kepada Tuhan), dan horizontal (kepada orang lain). Berpijak dari pandangan itu maka, manusia harus memposisikan diri sebagai Khalifah (pemimpin), Abdullah (hamba), dan bagian dari masyarakat dalam menjamin kehidupan ke arah yang lebih baik.
\end{abstract}

Kata Kunci: Integratif-Interkonektif, Hormat, Tanggung Jawab

\title{
Pendahuluan
}

Keprihatinan terhadap krisis moral yang melanda negara kita, seperti tindakan kekerasan, perkelahian, pembunuhan, penggunaan obat-obat terlarang, penggunaan kata-kata dan bahasa yang memburuk sampai ujaran kebencian, merebaknya pergaulan bebas, bias antara baik dan buruk sehingga orang jujur dimusuhi, orang berbohong dijadikan teman, penghormatan terhadap orang tua dan orang tua semakin rendah serta berkurangnya kepedulian terhadap masyarakat dan negara, semangat kerja yang rendah, dan radikalisme 
yang merajalela. ${ }^{1}$ Abudin Nata mengatakan bahwa penyebab dari krisis moral adalah agama tidak dijadikan titik pusat acuan serta diiringi oleh derasnya arus budaya materalistik, hedonistik, dan skularistik. ${ }^{2}$

Menelisik dari problematika di atas, maka urgensi pendidikan karakter dan penanaman nilai-nilai utama karakter serta peningkatan intesitas, dan kualitasnya ${ }^{3}$ harus terselenggara dengan baik, ${ }^{4}$ guna mewujudkan manusia yang mampu mengembangkan potensi yang dimilikinya secara kreatif, mandiri, sehat, cakap, beradab, toleransi, demokratis dan bertanggung jawab dalam bingkai iman dan taqwa. ${ }^{5}$

Tulisan ini akan mengulas pemikiran Thomas Lickona tentang karakter tanggung jawab dan hormat sebagai sebuah nilai utama karakter secara universal dan menyentuh setiap aspek dari kehidupan manusia karena direpresentasikan moralitas dan hukum moral. Sehingga keduanya memiliki arti penting bagi kelansungan hidup yang demokratis dan humanis yang ditopang dengan kesehatan jiwa sehingga menjadi pribadi yang menjunjung tinggi kedamaian dan keadilan. ${ }^{6}$ Hormat dan tanggung jawab merupakan bagian yang integral dari karakter. Sehingga proses, pelaksanaan, dan implemetasi nyata dalam kehidupan tidak boleh berhenti, mesti dilakukan secara terus menerus, holistik, dan terintegrasi. Orientasi yang diharapkan dari terpatrinya sikap hormat dan tanggung jawab adalah

${ }^{1}$ Thomas Lickona, Pendidikan Karakter: Panduan Lengkap Mendidik Siswa Menjadi Pintar dan Baik.., hlm. 15-22. Baca juga, Juwariah dkk, Pendidikan Karakter Perspektif Pendidikam Islam, editor Sukiman (Yogyakarta: Fakultas Tarbiyah dan keguruan UIN Sunan Kalijaga, 2013), hlm. 35.

${ }^{2}$ Siti Farida, "Pendidikan Karakter Dalam Prespektif Islam," Kabilah: Journal Of Social Community 1, No. 1 (1 Juni 2016): 198-207, Hlm. 202.

${ }^{3}$ Bambang Dalyono dan Enny Dwi Lestariningsih, "Implementasi Penguatan Pendidikan Karakter Di Sekolah," Bangun Rekaprima: Majalah Ilmiah Pengembangan Rekayasa, Sosial Dan Humaniora 3, no. 2, Oktober (11 Oktober 2016): 33-42, https://doi.org/10.32497/bangunrekaprima.v3i2, Oktober.865, hlm. 35.

${ }^{4}$ Ajat Sudrajat, “Mengapa Pendidikan Karakter?," Jurnal Pendidikan Karakter 1, no. 1 (4 Oktober 2011), https://doi.org/10.21831/jpk.v1i1.1316, hlm 48.

5“UU_no_20_th_2003.pdf," diakses 14 Maret 2020, https://kelembagaan.ristekdikti.go.id/wpcontent/uploads/2016/08/UU_no_20_th_2003.pdf.

${ }^{6}$ Thomas Lickona, Educating For Character: Mendidik untuk Membentuk Karakter, Ed. 2, terj. Juma Abdu Wamaungo (Jakarta: Bumi Aksara, 2013), hlm. 15. 
terbentuknya pribadi menjadi masyarakat yang baik, ${ }^{7}$ serta kehidupan yang berperadaban dengan kepribadian yang berakhlaqul karimah. ${ }^{8}$

Menginternalisasikan sikap hormat dan tanggung jawab dalam membentuk manusia yang berkarakter merupakan suatu upaya yang sistematis dalam menanamkan suri tauladan yang orientasinya adalah menanamkan nilai-nilai dalam kehidupan, baik berupa etika, estetika, budaya, dan agama yang pada akhirnya terwujud pribadi yang berkemampuan melakukan pengendalian diri sehingga menjadi pribadi yang utuh dan berakhlakul karimah, dan berkemampuan dibidang keagamaan dan terampil dalam segala bidang yang dibutuhkan. ${ }^{9}$ Lebih lanjut, Maragustam menyatakan bahwa nilai hormat dan tanggung jawab merupakan bagian dari spritualitas keagamaan dan sangat ditekankan dalam Islam. ${ }^{10}$

Penelitian-penelitian terdahulu yang mengkaji tentang hormat dan tanggung jawab sebagai nilai utama karakter perspektif Thomas Lickona belum banyak dilakukan.Kecenderungan penelitian terdahulu hanya mengkaji tentang pendidikan karakter menurut Thomas Lickona secara umum, seperti.Penelitian yang dilakukan oleh Dalmeri yang mengkaji pemikiran Thomas Lickona tentang karakter dalam buku educating for character fokus penelitiannya pada konsep pendidikan karakter menurut Thomas Lickona. ${ }^{11}$ Penelitian Muh. Idris mencoba mengkaji tentang pendidikan karakter perspektif Islam dan Thomas Lickona. Akan tetapi penelitian tersebut masih fokus pada

7Juwariah dkk, Pendidikan Karakter Perspektif Pendidikam Islam, editor Sukiman (Yogyakarta: Fakultas Tarbiyah dan keguruan UIN Sunan Kalijaga, 2013),hlm 36.

${ }^{8}$ Hadi Machmud, “Urgensi Pendidikan Moral Dalam Membentuk Kepribadian Anak," Jurnal Al-Ta'dib 7, no. 2 (2014): 75-84, hlm. 76.

${ }^{9}$ Agus Fakhruddin, "Urgensi Pendidikan Nilai Untuk Memecahkan Problematika Nilai Dalam Konteks Pendidikan Persekolahan," Jurnal Pendidikan Agama Islam- Ta'lim 12, no. 1 (2014): 79-96, hlm. 96. Baca juga, Ani Nur Aeni, Pendidikan Nilai, Moral, dan Krakter (Bandung: UPI Press, 2018).

${ }^{10}$ Maragustam, Filsafat Pendidikan Islam Menuju Pembentukan Karakter (Yogyakarta: Pascasarjana. Fakultas Ilmu Tarbiyah dan Keguruan UIN Sunan Kalijaga, 2018), hlm. 271.

${ }^{11}$ Dalmeri Dalmeri, "Pendidikan Untuk Pengembangan Karakter (Telaah Terhadap Gagasan Thomas Lickona Dalam Educating For Character)," Al-Ulum 14, no. 1 (1 Juni 2014): 269-88. 
pembahasan tentang karakter perspektif islam dan Thomas Lickona. ${ }^{12}$ Berbeda dengan penelitian Masrurah Lubis yang mencoba membedah pemikiran karakter menurut Islam dan Barat dengan cara melakukan study komparatif antara pemikiran karakter Nashih Ulwan dan Thomas Lickona. ${ }^{13}$ Zaidi Salim, Djam'annuri, Aminullah juga melakukan studi komparatif terkait dengan konsep pendidikan karakter menurut al-Ghazali dan Thomas Lickona. ${ }^{14}$ Tidak jauh berbeda dengan penelitian tersebut, Iwan Kuswadi mengkaji terkait dengan tahap perkembangan moral perspektif Islam dan Barat dengan fokus kajian terhadap perspektif Thomas Lickona, Lowrence Kohlberg, dan Al-Qur'an. ${ }^{15}$

Menilisik dari kecenderungan penelitian di atas. Maka artikel ini akan mengkaji perspektif Thomas Lickona tentang hormat dan tanggung jawab yang kemudian diintegrasikan dan interkoneksikan dengan nilai-nilai islam. Permasalaahan yang akan ditelisik dalam artikel ini adalah konsep dasar dari nilai tanggung jawab dan hormat berlandaskan pemikiran Thomas Lickona dan perspektif Islam, serta urgensinya dalam konteks kehidupan dan pendidikan. Peneliti berargumen bahwa nilai hormat dan tanggung jawab merupakan bagian dari ajaran Islam, karena hormat dan tanggung jawab akan menuntun manusia menjadi manusia yang berkarakter baik dalam konteks hubungan secara vertikal dengan sang pencipta (hablu minaallah) maupun hubungan secara horizontal dengan sesama manusia (hablu mina al-nas).

\footnotetext{
${ }^{12}$ Muh Idris, "Pendidikan Karakter: Perspektif Islam Dan Thomas Lickona," Ta'dibi : Jurnal Manajemen Pendidikan Islam 7, no. 1 (3 September 2018): 77-102.

${ }^{13}$ Masruroh Lubis, "Konsep Pendidikan Karakter Dalam Perspektif Islam dan BaraT (Studi Komparatif Pemikiran Nashih Ulwan Dan Thomas Lickona)," Al-Fikru 12, no. 2 (24 Maret 2019), http://alfikru.staiserdanglubukpakam.ac.id/index.php/alfikru/article/view/23.

${ }^{14}$ Nur Zaidi Salim, Djam'annur, Dan Aminullah, "Studi Komparasi Konsep Pendidikan Karakter Anak Menurut Al-Ghazali dan Thomas Lickona," Manarul Qur'an: Jurnal Ilmiah Studi Islam 18, No. 2 (2018): 135-53.

${ }^{15}$ Iwan Kuswandi, “Tahapan Pengembangan Moral: Perspektif Barat dan Islam (Telaah Terhadap Gagasan Thomas Lickona, Lawrence Kohlberg Dan AlQur'an)," Ar-Risalah: Media Keislaman, Pendidikan Dan Hukum Islam 18, no. 1 (7 Mei 2020): 158-73, https://doi.org/10.29062/arrisalah.v18i1.329.
} 
Studi pustaka menjadi acuan utama dalam artikel ini yaitu dengan menggali tulisan-tulisan dalam buku maupun artikel dan berbagai laporan yang berkaitan dengan problem yang ingin dikupas. Studi pustaka atau library research juga berarti suatu proses analisis untuk mendapatkan sebuah landasan teori yang berkaitan dengan hasil dan referensi-referensi dari kajian-kajian yang sebelumnya.

Integrasi-interkoneksi keilmuan menjadi perspektif yang digunakan dalam penelitian ini untuk menggambarkan perspektif Thomas Lickona dan perspektif Islam yang common matter integrated with religious matter and religious matter integrated with common matter. ${ }^{16}$ Perspektif itu diyakini akan dapat membantu manusia dalam memecahkan persoalan yang dihadapi. ${ }^{17}$ Sehingga aplikasi integrasiinterkoneksi keilmuan dalam tataran kehidupan bermasyarakat sangat diperlukan. ${ }^{18}$

Hal itu disebabkan karena tujuan yang ingin dicapai dari pendidikan khususnya pendidikan Islam tidak hanya terpangku pada proses transfer of knowledge, tetapi juga yang tidak kalah penting adalah transfer of Islamic values. ${ }^{19}$ Karena Islam sebagai agama, tidak datang begitu saja dengan tangan hampa. Hadirnya islam tidak hanya membawa seperangkat keyakinan, tradisi, serta beragam praktik peradaban, tapi juga membawa esensi moral dan standar nilai. ${ }^{20}$ Oleh karena itu, wacana integrasi pengetahuan agama dengan pengetahuan

${ }^{16}$ Afiful Ikhwan, “Integrasi Pendidikan Islam (Nilai-Nilai Islami Dalam Pembelajaran)," Ta'allum: Jurnal Pendidikan Islam 2, no. 2 (1 November 2014): 179-194194, https://doi.org/10.21274/taalum.2014.2.2.179-194, hlm. 193.

${ }^{17}$ Amin Abdullah, Islmaic Studies Di Perguruan Tinggi Sebuah Pendekatan Integratif-Interkonektif (Yogyakarta: Pustaka Pelajar, 2012). Disampaikan lagi dalam acara Stadium General Pasca Sarjana, Interdisciplinary Islamic Studies pada hari senen 9 Seftember 2019.

${ }^{18}$ Eka Saftri dan Ihsan Sa'dudin, “Aplikasi Integrasi Interkoneksi Keilmuan di Lembaga Pendidikan Tinggi," Tadrib 5, no. 1 (1 Juli 2019): 122-37, https://doi.org/10.19109/tadrib.v5i1.2731, hlm 128.

${ }^{19}$ Triwidiyastuti dan Maragustam Siregar, "The Concept of Islamic Education Development Based On The Theory of Fitrah," Indonesian Journal of Interdisciplinary Islamic Studies (IJIIS) 2, no. 1 (2018): 31-52, https://doi.org/10.20885/ijiis.vol2.iss1.art2, hlm. 32.

${ }^{20}$ Lukis Alam, Sekolah Islam Elite, Integrasi Kurikulum dan Aspirasi Kelas Menengah Muslim di Daerah Istimewa Yogyakarta, Disertasi Dokotoral (Yogyakarta: UIN Sunan Kalijaga Yogyakarta, 2019), hlm.27-8. 
umum berangkat dari sebuah keprihatinan terhadap pendidikan yang kurang dalam pembentukan moralitas dan etika sering dengan meningkatnya kesadaran umat islam terhadap pola pendidikan yang menggabungkan cara pandang Islam yang lebih komprehensif. ${ }^{21}$

Sumber data dari artikel ini adalah berupa data primer dan sekunder. Sumber primernya adalah buku Educating for Character ${ }^{22}$ dan buku pendidikan karakter $^{23}$ yang ditulis oleh Thomas Lickona. Substansi dari buku tersebut tidak menggambarkan perbedaan yang signifikan. Namun peneliti tetap menjadikan kedua buku tersebut menjadi rujukan primer. Adapun rujukan sekunder dari artikel ini adalah artikel-artikel yang relevan dengan tema yang akan dikaji kemudian didokumentasikan dan dianalisis dengan metode diskriptifanalitik.

\section{Pembahasan}

\section{Konsep Dasar Hormat dan Tanggung Jawab Perspektif Thomas Lickona}

Pondasi awal dari gagasan Thomas Lickona terkait nilai utama karakter, berakar rumput pada perbincangan tentang nilai atau tuntunan moral. Peneliti dalam konteks ini akan membincangkan tentang nilai sebagai langkah pertama dalam melihat gagasan dari Thomas Lickona. Roeckh (1973) dalam Rahmat Mulyana membagi nilai menjadi dua, yakni nilai instrumental yang berarti nilai antara dan nilai terminal yang menjadi nilai akhir. Nilai yang bersifat instrumental biasanya akan sering terlihat pada perilaku seseorang, dimana nilai tersebut hanya menjadi bagian luar dari nilai dan sistem perilaku itu sendiri. Adapun untuk nilai terminal justru menjadi bagian yang tersembunyi di belakang nilai-nilai instrumental dalam perilaku. ${ }^{24}$ Kaitannya dengan hormat dan tanggung tanggung jawab dalam artikel ini bahwa hormat masuk dalam ketegori nilai terminal atau nilai akhir yang dihasilkan dari ketaatan.Sedangkan tanggung

\footnotetext{
${ }^{21}$ Ibid..., hlm.5, 15.

${ }^{22}$ Lickona, Educating For Character: Mendidik untuk Membentuk Karakter.

${ }^{23}$ Lickona, Pendidikan Karakter: Panduan Lengkap Mendidik Siswa Menjadi Pintar
} dan Baik.

${ }^{24}$ Rohmat Mulyana, Mengartikulasikan Pendidikan Nilai, 2 ed. (Bandung: alFabeta, 2011), hlm. 26-7. 
jawab masuk dalam kategori nilai instrumental atau nilai prantara yang kemudian menghasilkan persahabatan abadi.

Nilai yang diyakini oleh semua manusia sebagai ikatan dalam kehidupan diklasifikasikan dalam dua macam yakni nilai moral dan nonmoral. Moral dalam bahasa disebut "Moralitas" yang bemakna sebuah penyebutan terhadap tindakan orang lain yang mengandung sisi positif. ${ }^{25}$ Sedangkan nonmoral atau tidak bermoral merupakan kebalikan dari moral atau moralitas. Lickona mengatakan bahwa di dalam nilai moral terkandung sebuah kewajiban untuk bersikap jujur, amanah, dan adil. Artinya bahwa moral itu adalah sesuatu yang mendorong kita untuk melakukan tindakan bermoral meski terkadang kita tidak memiliki keinginan untuk melakukannya. Berbeda dengan nilai nonmoral adalah perilaku yang ditunjukkan oleh personal yang kemudian tidak dibenarkan dan diinginkan oleh orang lain.

Lickona kemudian membagi nilai moral dalam kategori universal dan nonuniversal. universal berarti memberikan kebebasan dengan perlakuan baik dan menghargai pilihan hidup orang lain, serta perlakuan yang sama kepada semua orang dalam dalam setting social yang berbeda dengan mengutamakan penghargaan dan nilai kemanusiaan. Adapun non-universal merupakan suatu kewajiban yang berlaku bagi pemeluk agama tertentu dalam menjalankan ketatannya, secara individual diakui sebagai tuntutan yang mesti dilaksanakan, namun dalam perspektif penganut agama yang lain belum tentu dirasakan sama seperti individu yang lain. ${ }^{26}$

Pada intinya sikap hormat dan tanggung jawab sebagai nilai utama karakter menurut Thomas Lickona didasarkan pada hukum moral yang menuntut dan mendorong kita untuk melakukan tindakan itu. Sehingga sikap hormat dan tanggung jawab itu kemudian penting untuk diinternalisasikan dalam konteks kehidupan bermasyarakat maupun pendidikan sebagai tangga awal dalam mewujudkan manusia yang berkarakter. Penegasan tentang pentingnya penekanan terhadap dua modal utama dalam pendidikan karakter menurut Lickona disebabkan karena manusia modern telah mabuk dan lupa

${ }^{25}$ Ani Nur Aeni, Pendidikan Karakter untuk Mahasiswa PGSD (Bandung: UPI Press, 2014), hlm.38.

${ }^{26}$ Thomas Lickona, Educating For Character: Mendidik untuk Membentuk Karakter..., hlm. 61-3. 
akan hak yang harus dilakukannya, karenanya kemudian tanggung jawab dapat dijadikan sebagai langkah koreksi terhadap problematika tersebut. Lebih lanjut ia mengatakan bahwa salah satu tantangan moral zaman sekarang adala bagaimana menyeimbangkan antara hak dan kewajiban serta membesarkan anak-anak supaya memiliki rasa tanggung jawab besar terhadap hak dan kewajiban. ${ }^{27}$

\section{Integrasi-Interkoneksi Konsep Hormat dan Tanggung Jawab Perspektif Thomas Lickona dan Perspektif Islam}

Islam sebagai agama rahmatan lil alamiin memberikan dan petunjuk tuntunan sebagai pedoman dalam menjalani hidup bagi pemeluknya sehingga universalisme islam adalah menyentuh seluruh aspek kehidupan manusia tidak tekecuali bagaimana memberikan penghormatan dan memegang pertanggung jawaban. Penghormatan diawali dari diri sendiri dan merupakan sikap yang menunjukkan pribadi manusia yang cerdas dalam mensyukuri nikmat yang diberikan Tuhan kepadanya. Aktualisasi dari sikap hormat terhadap diri sendiri kemudian diaplikasikan di kehidupan dalam betuk mendayagunakan setiap potensi yang diberikan Tuhan untuk kebaikan dirinya dan orang lain disekitarnya. Internalisasi sikap hormat terhadap diri sendiri akan menuntut pribadi masing-masing manusia untuk dengan sebaik-baiknya tanpa menjerumuskan diri ke jalan yang dapat mendatangkan kerusakan. Hormat bermakna sebuah penghargaan yang ditujukkan kepada individu maupun terhadap sesuatu yang lain di luar. Sehingga komponen penting yang terdapat dalam rasa hormat tersebut adalah sikap hormat kepada orang lain maupun kepada lingkungan sekitar, dan tentunya sikap hormat tidak terlepas terhadap diri sendiri. ${ }^{28}$

Menghormati diri sendiri adalah perlakuan diri sebagai sesuatu yang memiliki nilai inheren, artinya memandang diri sendiri sebagai manusia yang diberikan potensi oleh Tuhan yang kemudian dimanfaatkan dengan baik tidak digunakan untuk merusak diri sendiri. Sehingga hormat terhadap diri sendiri kemudian dijadikan

\footnotetext{
${ }^{27}$ Lickona, Pendidikan Karakter: Panduan Lengkap Mendidik Siswa Menjadi Pintar dan Baik.., hlm. 64.

${ }^{28}$ Lickona, Pendidikan Karakter: Panduan Lengkap Mendidik Siswa Menjadi Pintar dan Baik, hlm.62.
} 
pegangan bahwa kerusakan fungsi tubuh yang ditimbulkan dari penggunaan barang terlarang merupakan tindakan yang tidak dibenarkan.

Menghormati diri sendiri adalah perlakuan diri sebagai sesuatu yang memiliki nilai inheren, artinya memandang diri sendiri sebagai manusia yang diberikan potensi oleh Tuhan yang kemudian dimanfaatkan dengan baik tidak digunakan untuk merusak diri sendiri. Sehingga hormat terhadap diri sendiri kemudian dijadikan pegangan bahwa kerusakan fungsi tubuh yang ditimbulkan dari penggunaan barang terlarang merupakan tindakan yang tidak dibenarkan.

Rasa hormat yang dimiliki oleh seseorang dalam pandangan Lickona dapat dilihat dari penghormatan yang diberikan terhadap sesuatu yang dimiliki, dimana ketika seseorang memiliki rasa hormat, ia akan merasa apapun yang ada merupakan bagian dirinya. Hal tersebut juga tak terkecuali dengan rasa hormat terhadap suatu kewenangan, dimana ketika seseorang telah memiliki pemahaman terhadap gambaran legitimasi wewenang yang baik sebagai kepedulian terhadap orang lain, ia akan menyadari bahwa tanpa pihak yang memiliki wewenang ia tidak akan mampu menjalani kehidupan negara, sosial maupun keluarga dengan aman. Sebaliknya, ketika seseorang tidak memiliki penghargaan terhadap suatu kewenangan yang diberlakukan, kemungkinan terbesar sistem kehidupan tidak mampu berjalan dengan baik dan menyebabkan banyak kerugian terhadap orang lain. ${ }^{29}$ Lickona menambahkan bahwa a hormat kepada manusia adalah bentuk dari sopan santun yang paling mendasar. ${ }^{30}$ Sehingga implementasi dari rasa hormat dapat diwujudkan melalui suatu keinginan untuk bersikap sopan dan beradab dalam memandang orang lain, memperlakukan lingkungan dan dirinya sendiri dengan cara yang lebih baik. ${ }^{31}$

${ }^{29}$ Lickona, Educating For Character: Mendidik untuk Membentuk Karakter, hlm. 71.

${ }^{30} \mathrm{Ibid} . . .$, , hlm. 72-3.

${ }^{31}$ Sigit Dwi Laksana, "Urgensi Pendidikan Karakter Bangsa Di Sekolah," Muaddib: Studi Kependidikan dan Keislaman 5, no. 2 (4 April 2016): 167-84, https://doi.org/10.24269/muaddib.v5i2.67.

190 
Adapun sikap menghormati orang lain adalah perlakuan kita kepada orang lain tanpa memandang sisi negatifnya karena pada hakikatnya semua manusia memiliki kedudukan yang sama. Pernghargaan dan penghormatan kepada orang lain adalah implikasi dari perlakuan terhadap diri sendiri, sehingga makna "Golden Rule" adalah perintah untuk menyeimbangkan perlakuan terhadap orang lain harus sama dengan perlakuan yang diberikan kepada diri. Oleh karena itu, menghormati adalah tindakan dan sikap menghargai dan mengakui keberhasilan orang lain dalam usaha menghadirkan kebermanfaatan dari hasil didapatkan untuk keperluan masyarakat luas. $^{32}$

Sikap hormat terhadap orang lain mununjukkan sikap humanis dengan orang lain dan memandangnya sebagai pribadi yang memiliki aspek-aspek positif. Dalam islam sikap humanis sangat ditekankan karena sangat menghargai manusia ${ }^{33}$ yang di dalamnya terkumpul naluri ketuhanan dan naluri alamiah yang tidak pernah bertentangan dan saling mengisi. ${ }^{34}$ Sikap humanis menurut aliran humanistik adalah menganggap manusia adalah aspek studi terpenting untuk menciptakan kehidupan yang lebih baik serta menghidupkan rasa kepedulian terhadap manusia. Dalam al-Qur'an kemudian dijelaskan bahwa term tentang manusia dijelaskan dari empat aspek, yakni; 1) al-Basyar, berarti sesuatu yang baik dan indah. 2) An-Nas, yang dihubungkan dengan fungsi manusia sebagai makhluk sosial. 3) Bani Adam, berarti bahwa manusia adalah makhluk rasional. 4) al-Insan berarti, makhluk yang jinak, harmonis, dan tampak. ${ }^{35}$

\footnotetext{
32Maragustam, "Paradigma Holistik-Integratif-Interkonektif Dalam Filsafat Manajemen Pendidikan Karakter," Jurnal Studi Agama dan Masyarakat 11, no. 1 (2015): 122-44, https://doi.org/10.23971/jsam.v11i1.409, hlm. 135.

${ }^{33}$ Fuad Nashori Suroso, Agenda Psikologi Islam, 2 ed. (Yogyakarta: Pustaka Pelajar, 2010), hlm.37.

${ }^{34}$ Husna Amin, “Aktualisasi Humanisme Religius Menuju Humanisme Spiritual Dalam Bingkai Filsafat Agama," SUBSTANTIA 15, no. 1 (15 April 2013): 6680, https://doi.org/10.22373/subtantia.v15i1.4885, hlm. 66.

${ }^{35}$ Ahmad Zain Sarnoto dan Mohammad Muhtadi, "Pendidikan Humanistik Dalam Perspektif Al-Qur'an," Alim I Journal of Islamic Education 1, no. 1 (2 April 2019): 21-46, hlm. 35-8.
} 
Penekanan dari sikap hormat terhadap orang lain adalah memandangnya sebagai manusia yang diberikan peluang untuk berkembang dengan segala potensi yang dianugerahi oleh Tuhan sebagai makhluk sosial, sebagai Abdullah dan Khalifatullah..$^{36}$ Sehingga pribadi humanis akan berusaha dan memperjuangkan sebuah kehidupan ideal sebagai hasil dari sikap mengargai orang lain. sebagaimana dalam hadist dijelaskan

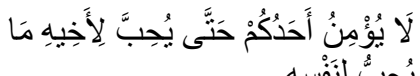

"kesampurnaan iman seseorang dapat diukur melalui tingkat penghargaan dan kecintaan terhadap saudaranya sebagaimana kecintaannya terhadap dirinya"37

Sedangkan sikap hormat terhadap lingkungan kehidupan tanpa terkecuali bermakna sebuah perintah untuk merawat dan melindungi lingkungan dan alam serta larangan untuk berbuat kejam atau mengekploitasi. Pribadi yang memiliki rasa hormat terhadap jaringan kehidupan akan menjadi pribadi yang mampu berinteraksi dengan lingkungan dan menciptakan serta mengolah lingkungan dengan baik.

Hormat terhadap lingkungan hidup atau alam sekitar adalah bentuk dari kepedulian terhadap lingkungan dengan cara merawat, menjaga, dan melestarikannya, karena apapun yang ada di lingkungan tersebut dapat dimanfaatkan dan digunakan untuk keperluan sehari-hari, bukan untuk dieksploitasi dan dirusak. Sebagaimana yang Allah jelaskan dalam surat al-Rum 30[41].

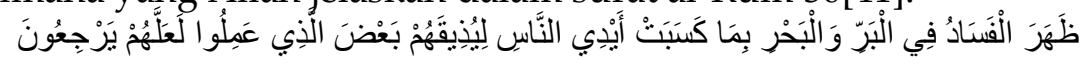
"Terlihat dengan jelas berbagai macam kerusakan di bumi dan di laut akibat dari ulah tangan manusia, sehingga Allah kemudian menimpakan kepadannya akibat dari perbuatannya, supaya mereka kembali ke jalan yang benar". 38

${ }^{36}$ Hendro Widodo, "Pengembangan Respect Education Melalui Pendidikan Humanis Religius di Sekolah," Lentera Pendidikan: Jurnal Ilmu Tarbiyah dan Keguruan 21, no. 1 (30 Juni 2018): 110-22, https://doi.org/10.24252/lp.2018v21n1i10, hlm. 113

37 Software Gawami' Al-Kalim. Kitab Shahih Bukhari, No Hadist.13. Software Gawami' Al-Kalim ini merupakan software pencarian hadist yang di dalamnya terdapat 1400 kitab hadist, baca Ali Imran, Metodologi Penelitian Hadist Nabi dengan Software Gawami' Al-Kalim V.4.5.(Yogyakarta: Q-Media, 2019), hlm. 1.

${ }^{38}$ QS. Al-rum: 30[41]. 
Maragustam memandang nilai hormat atau menghargai merupakan bentuk dari cinta dan kasih sayang serta menunjukkan penghargaan sehingga islam menekankan dengan memberikan pandangan yang dilatar belakangi oleh cara pandang terhadap manusia berasal dari tulang rusuk yang sama walapun berbeda secara jenis kelamin, ras, suku, bangsa dan negara. Hanya ketaqwaan yang menjadi penentu rendah dan tingginya derajat manusia di sisi Allah, memiliki kesamaan tugas kepada Ilahi dan sadar akan posisi sebagai masyarakat. Sikap menghargai akan berjalan dengan baik apabila didasari dengan cinta dan kasih sayang, sehingga seseorang akan menyadari bahwa dirinya tidak dapat terpisahkan dari masyarakat dan akan merasa mudah menghargai orang lain. ${ }^{39}$

Sikap menghargai akan berjalan dengan baik apabila didasari dengan cinta dan kasih sayang, sehingga seseorang akan menyadari bahwa dirinya tidak dapat terpisahkan dari masyarakat dan akan merasa mudah menghargai orang lain..$^{40}$ Sehingga implementasi dari rasa hormat dapat diwujudkan melalui suatu keinginan untuk bersikap sopan dan beradab dalam memandang orang lain, memperlakukan lingkungan dan dirinya sendiri dengan cara yang lebih baik. ${ }^{41}$

Sikap hormat kemudian menjadi akar rumput dari terbentuknya sikap tanggung jawab sebagaimana yang ditegaskan oleh Thomas Lickona yang bermakna suatu kemampuan untuk memegang amanah yang dibebankan. Sukanto (1985) dalam Mustari ${ }^{42}$ menyatakan bahwa manusia secara kodrati memiliki tanggung jawab sacara personal, moral, dan sosial sehingga menghadirkan makna tanggung jawab secara luas dalam bentuk ketataan, kesyukuran kepada Tuhan terhadap Tuhan, memelihara diri dari segala bentuk

272.

${ }^{39}$ Maragustam, Filsafat Pendidikan Islam Menuju Pembentukan Karakter, hlm.

${ }^{40}$ Maragustam, Filsafat Pendidikan Islam Menuju Pembentukan Karakter, hlm.

272.

${ }^{41}$ Sigit Dwi Laksana, "Urgensi Pendidikan Karakter Bangsa Di Sekolah," Muaddib: Studi Kependidikan dan Keislaman 5, no. 2 (4 April 2016): 167-84, https://doi.org/10.24269/muaddib.v5i2.67.

${ }^{42}$ Muhammad Mustari, Nilai Karakter: Refleksi untuk Pendidikan, 1 ed., Editor Taufik Rahman (Jakarta: Raja Grafindo Persada, 2014).., hlm. 20-1. 
ancaman, penindasan, penyiksaan, dan kekejaman, berlebihan dan kerasukan ekonomi, menafkahi keluarga, bersosial dengan masyarakat, berpikir, menjaga tatanan kehidupan dan lingkungan..$^{43}$

Secara bahasa tanggung jawab memiliki arti "kekuatan menanggung, merespons atau menjawab". Tanggung jawab berorientasi terhadap orang lain seperti memberikan perhatian ataupun merespon apa yang diinginkan orang lain. Selain itu, tanggung jawab juga memberi penekanan terhadap suatu kewajiban positif kepada individu agar dapat memberikan perlindungan satu sama lain. ${ }^{44}$ Lickona menambahkan bahwa makna lain dari tanggung jawab adalah bisa diandalkan dan tidak mengecewakan. Sehingga pekerjaan dan kewajiban akan dilaksanakan dengan cara terbaik dan dengan hati yang tulus ikhlas. ${ }^{45}$

Sikap dan perilaku dalam melaksanakan tugas dan kewajiban sebagaimana yang harus lakukan, terhadap diri sendiri, masyarakat, lingkungan (alam, sosial, dan budaya), Negara, dan Tuhan merupakan konsistensi dalam menjalankan amanah. ${ }^{46}$ Sehigga Maragustam menyatakan bahwa kata-kata, perilaku, dan sikap dalam menjalankan pekerjaan yang dibebankan kepada dirinya, masyarakat, lingkungan (alam, sosial, budaya, dan tradisi), Negara, dan Allah Swt baik di dunia maupun akhirat ${ }^{47}$ dan merupakan lanjutan dari spiritual keagamaan (makrifatullah) sebagai esensi dari tanggung jawab. ${ }^{48}$

Dalam perspektif islam, tanggung jawab juga meliputi tiga bagian yaitu pertama, secara vertical, dimana bagian ini mengarah kepada hubungan seseorang dengan sesuatu yang diluar dari dirinya namun memiliki kekuatan lebih atas kehidupannya, yaitu Tuhan. Kedua, secara horizontal yaitu lingkungan sekitar. Ketiga, secara

${ }^{43}$ Ibid..., hlm. 21-4.

${ }^{44}$ Lickona, Pendidikan Karakter: Panduan Lengkap Mendidik Siswa Menjadi Pintar dan Baik, hlm 63.

${ }^{45}$ Lickona, Educating For Character: Mendidik untuk Membentuk Karakter..,hlm. 73.

${ }^{46}$ Muhammad Mustari, Nilai Karakter: Refleksi untuk Pendidikan, 1 ed., Editor Taufik Rahman, (Jakarta: Raja Grafindo Persada, 2014), hlm. 19.

${ }^{47}$ Maragustam, Filsafat Pendidikan Islam Menuju Pembentukan Karakter, hlm. $274-75$.

${ }^{48}$ Maragustam, "Paradigma Holistik-Integratif-Interkonektif Dalam Filsafat Manajemen Pendidikan Karakter..., hlm. 134 
personal, dimana bagian ini menyangkut substansi pribadi diri sendiri. Tiga bagian tersebut kemudian diklasifikasikan oleh Maragustam sebagai bentuk lain dari tanggung jawab. Maragustam mengklasifikasikan tanggung jawab dalam lima macam, yakni; tanggung jawab kepada Tuhan, kepada diri sendiri, keluarga, masyarakat, serta bangsa dan negara. ${ }^{49}$

Perluasan dari perspektif Maragustam di atas, Anwar mengemukakan klasifikasi tanggung jawab:

1. Tanggung jawab terhadap Allah berbentuk; mengabdikan diri sebagai hamba dan khalifatullah kepada-Nya, menjaga kesucian Islam dengan menjalankan setiap ajarannya.

2. Tanggung jawab kepada diri sendiri berbentuk; pembersihan diri secara jasmani dan rohani, mengembangkan setiap potensi-potensi yang dimiliki.

3. Bertanggung jawab terhadap amanah yang dibebankan dan harus dikerjakan sesuai yang diperintahkan.

4. Tanggung jawab terhadap keluarga sebagai ilustrasi, ayah memberikan rasa aman terhadap istri dan anak-anaknya baik berbentuk kebutuhan primer maupun sekunder. Istri mendidik, menjaga, dan memelihara harta dan anakanaknya secara jasmani maupun rohani. Anak bertanggug jawab untuk berbakti kepada orang tua serta menjaga nama baik keluarga.

5. Tanggung jawab kepada masyarakat bermakna setiap sikap, perkataan, dan tindakan sebagai bagian dari masyarakat harus dipertanggung jawabkan kepada masyarakat. perwujudan dari tanggung jawab dalam islam adalah; meningkatkan kemakmuran masyarakat dengan iman dan taqwa kepada Allah, menjalin hubungan Ukhuwwah Islamiyah dan silaturahim, saling tolong menolong dalam kebaikan, saling nasehat menasehati, tidak memarahi dan mendiamkan saudara selama tiga hari, menutupi aib sesama muslim, dan menjaga kehormatan jiwa dan harta saudaranya.

${ }^{49}$ Maragustam, Filsafat Pendidikan Islam Menuju Pembentukan Karakter..., hlm. $275-76$. 
6. Keterikatan manusia oleh aturan, dan hukum yang dibuat oleh Negara mengharuskan manusia untuk bertaggung jawab terhadap bangsa dan Negara, artinya bahwa manusia terikat oleh norma-norma, peraturan, dan hukum yang dibuat oleh Negara tersebut. sehingga apabila melakukan tindakan yang melanggar hukum, maka harus mempertanggung jawabkan perbuatannya itu sesuai dengan ketentuan yang dijalankan di negara itu.

7. Tanggung jawab terhadap lingkungan dan makhluk hidup lainnya, artinya harus memiliki peran untuk merawat, membersihkan, dan menjaga lingkungan maupun makhluk hidup yang ada di dalamnya. ${ }^{50}$

Islam memandang bahwa tanggung jawab penting adanya dan sangat ditekankan. ${ }^{51}$ Sebagaimana pesan Rasulallah bahwasannya seluruh manusia adalah pemimpin yang akan diminta pertanggung jawabanya. Pemimpin bagi diri, orang lain, keluarga, dan masyarakat. Islam memandang tanggung jawab tidak hanya sebatas menerima konsekuensi di dunia tapi juga diakhirat karena setiap individu akan diminta pertanggung jawabannya dihadapan Allah atas apa yang diperbuatnnya, ${ }^{52}$ karena terkadang kita juga lupa dan lalai akan tanggung jawab yang harus kita lakukakn. Bahkan kita sering melakukan hal-hal yang berlebihan dan bermegah-megahan sehingga membuat kita lalai. Padahal itu akan diminta pertanggung jawabannya kelak, sebagaimana yang dijelaskan dalam surat alTakaatsur. 102: 8.

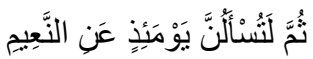

"Kenikmatan yang kamu megah-megahkan di dunia pasti akan ditanyakan kelak". 53

50Shabri Shaleh Anwar, "Tanggung Jawab Pendidikan Dalam Perspektif Psikologi Agama," Psympathic: Jurnal Ilmiah Psikologi 1, no. 1 (30 Juni 2014): 11-21, https://doi.org/10.15575/psy.v1i1.463, hlm. 14-20.

${ }^{51}$ Maragustam, Filsafat Pendidikan Islam Menuju Pembentukan Karakter..., hlm.275.

${ }^{52 E l f i ~ Y u l i a n i ~ R o c h m a h, ~ “ M e n g e m b a n g k a n ~ K a r a k t e r ~ T a n g g u n g ~ J a w a b ~ P a d a ~}$ Pembelajar (Perspektif Psikologi Barat dan Psikologi Islam)," AL-MURABBI: Jurnal Studi Kependidikan dan Keislaman 3, no. 1 (2 Juli 2016): 36-54, hlm. 52.

${ }^{53}$ QS, al-Takaastur: 102 [8]. 


\section{Urgensi Sikap Hormat dan Tanggug Jawab Dalam Konteks Pendidikan Karakter di Sekolah}

Kemerosotan moral merupakan problematika yang tidak hanya terjadi dimasyarakat namun sudah masuk dalam dunia pendidikan terutama terhadap peserta didik atau siswa yang pada akhirnya menimbulkan berbagai tindakan atau perilaku yang tidak bermoral seprti yang telah disebutkan dipendahuluan. Sehingga menginternalisasikan sikap hormat dan tanggung jawab dalam konteks kehidupan bermasyarakat maupun pendidikan menjadi pondasi awal dan tempat berpijak untuk mewujudkan peserta didik yang secara konkret menjunjung tinggi sikap menghargai dan tanggung jawab serta secara etis memposisikan diri di tengah masyarakat.

Dalam implementasinya, sikap menghargai dan bertanggung jawab menurut Thomas Lickona merupakan sebuah gagasan besar, karena sejatinya pendidikan nilai bertujuan untuk mengajarkan sikap yang demikian itu serta mengembangkan karakter untuk mempraktekkan nilai-nilai tersebut. Argumentasi yang mendasari sehingga Lickona mengatakan bahwa sikap hormat dan tanggung jawab merupakan sebuah gagasan besar adalah;

a. Bahwasannya pendidikan sepanjang sejarahnya di seluruh dunia bertujuan supaya manusia menjadi cerdas dan baik atau berkarakter.

b. Baik dalam hal ini didefinisikan sebagai penegasan akan harga diri kita sebagai manusia dan mendukung kebaikan individu maupun masyarakat.

c. Penghormatan dan pertanggung jawaban adalah bentuk moralitas publik yang berlaku secara universal sehingga dapat diajarkan. sikap hormat menunjukkan sikap menghormati harkat orang lain dan sesuatu, sedang tanggung jawab adalah sisi aktif moralitas.

d. Apabila siswa memiliki rasa hormat dan tanggung jawab dalam kehidupannya berarti guru telah mendidik siswa nya.

e. Alasan terakhirnya adalah kita semakin dihadapkan pada kondisi sosial yang semakin memburuk. Sehingga sekolah- 
sekolah harus memiliki pendekatan yang komprehensif dalam membangun karakter siswanya. ${ }^{54}$

Berangkat dari sebuah gagasan besar tentang urgensi dari sikap hormat dan tanggung jawab di atas kemudian Thomas Lickona memunculkan strategi penanaman nilai hormat dan tanggung jawab secara komprehensif, yakni strategi di dalam kelas dan strategi sekolah. Sinergitas dan dukungan dari para stecholder dan pemangku kebijakan sangat dibutuhkan. ${ }^{55}$ Tanpa itu semua peneliti berpandangan bahwa sikap hormat dan tanggung jawab yang diajarkan akan sulit realisasinya dalam kehidupan.

Sebuah pendekatan komprehensif di dalam kelas, menuntut guru untuk mengajarkan sikap hormat dan tanggung jawab dengan cara:

a. Bertindak sebagai pengasuh, teladan, pembimbing, penegur kesalahan, dan pemberi contoh sehingga siswa diperlakukan dengan hormat dan kasih sayang.

b. Menjadikan siswa saling mengenal, menjaga, dan mengormati sehingga tercipta komunitas yang baik di dalam kelas.

c. Menegakkan peraturan secara disiplin untuk mengontrol diri siswa dan sikap hormatnya kepada orang lain.

d. Menjadikan kelas sebagai lingkungan belajar yang demokratis, dimana siswa dilibatkan untuk mengambil keputusan atau pun tanggung jawab terhadap apa yang menjadi keputusannya.

e. Menjadikan proses belajar akademik sebagai sarana untuk mengkaji masalah-masalah etis dengan menyertakan nilainilai baik.

f. Bersikap kooperatif dalam dalam kegiatan belajar-mengajar sehingga terjalin kerja sama untuk saling membantu.

${ }^{54}$ Lickona, Pendidikan Karakter: Panduan Lengkap Mendidik Siswa Menjadi Pintar dan Baik.., hlm. 95-6

${ }^{55}$ Arif Billah, "Pendidikan Karakter untuk Anak Usia Dini dalam Perspektif Islam dan Implementasinya dalam Materi Sains," Attarbiyah: Journal of Islamic Culture and Education 1, no. 2 (2016): 243-72, https://doi.org/10.18326/attarbiyah.v1i2.243-272, hlm. 245. 
g. Mendorong pertumbuhan sikap tanggung jawab akademis dan sikap hormat siswa dengan mumbuhkan rasa empatinya melalui nilai-nilai dalam belajar dan bekerja.

h. Memberikan semangat kepada siswa dalam merefleksikan moral melalui membaca, menulis, berdiskusi, ataupun latihan membuat keputusan seperti memilih ketua kelas.

i. Membantu siswa untuk mencari penyelesaian atas suatu masalah yang ia hadapi, sehingga peserta didik memiliki kapasitas dan komitmen untuk memecahkan maslah, tanpa kekerasan. ${ }^{56}$

Adapun terkait dengan pendekatan komprehensif dalam mengajarkan sikap hormat dan tanggung jawab menuntut sekolah agar;

1. Menumbuhkan rasa kepedulian siswa baik di dalam maupun di luar kelas, dengan menggunakan model-model pembelajaran yang bervariasi dan kreatif, memberikan pelayanan sekolah dan lingkungan sekolah yang penuh toleransi serta kenyamanan sehingga siswa menyadari akan pentingnya sikap peduli terhadap orang lain.

2. Menciptakan budaya moral yang positif di sekolah dengan cara mengembangkan seluruh lingkungan sekolah melalui kedisiplinan seluruh tenaga pendidik di sekolah. Menumbuhkan perasaan sebagai anggota komunitas masyarakat dengan mengaplikasikan nilai-nilai moral yang diberikan saat proses belajar di dalam kelas, pada lingkungan sekolah, baik kepengurusan siswa yang demokratis maupun komunitas dikalangan lingkungan sekolah dengan berlandaskan nilai-nilai moral.

Membentuk kerjasama antara orang tua dan masyarakat di lingkungan sekolah untuk memberikan pendidikan nilai. Bentuk ubungan kerjasama yang dibangun yaitu memberikan dukungan kepada orang tua sebagai guru moral pertama anak; memberikan dorongan kepada sekolah dalam upaya menumbuhkan nilai-nilai yang baik; dan mengikut sertakan masyarakat sekitar sekolah untuk

${ }^{56}$ Lickona, Educating For Character: Mendidik untuk Membentuk Karakter..., hlm. $106-8$. 
turut andil dalam pemberian teladan kepada siswa, contohnya, dari organisasi keagamaan atau rumah ibadah, kalangan bisnis, dan media dalam menumbuhkan nilai-nilai yang hendak diajarkan di sekolah. ${ }^{57}$

\section{Kesimpulan}

Perspektif Thomas Lickona tentang hormat dan tanggung jawab sebagai nilai utama karakter yang penting untuk diinternalisasikan karena merupakan nilai karakter yang bersumber dari hukum moral yang kemudian menuntut manusia untuk melakuka hal itu. Sikap hormat berarti menunjukkan atau memberikan penghargaan baik terhadap diri sendiri, orang lain, maupun semua bentuk kehidupan dan lingkungan. Sikap bertanggug jawab adalah perluasan dari sikap hormat yang berarti sikap dan perilaku seseorang untuk melaksanakan tugas dan kewajiban sebagaimana yang seharusnya dia lakukan, terhadap diri sendiri, masyarakat, lingkungan (alam, sosial, dan budaya), Negara, dan Tuhan. Selain itu, islam juga memandangnya sebagai bagian dari ajaran-ajaran islam yang dilandasi atas dasar cinta dan kasih sayang sebagai respon secara vertikal (Tuhan), horizontal (orang lain), dan personal (pribadi). Urgensi dari sikap hormat dan tanggung jawab dalam konteks kehidupan dan pendidikan kemudian dapat dijadikan sandaran atau pondasi awal bagi masyarakat dan sekolah untuk mencetak manusia-manusia yang secara etis memposisikan diri sebagai bagian dari masyarakat yang menjunjung tinggi sikap menghargai atau hormat dan bertanggung jawab dalam kehidupan sebagai sikap yang memiliki arti konkret.Sehingga diperlukan sinergitas dan dukungan dalam mewujudkan manusia-manusia yang berkarakter.

\section{Daftar Pustaka}

Abdullah, Amin. Islmaic Studies Di Perguruan Tinggi Sebuah Pendekatan Integratif-Interkonektif. Yogyakarta: Pustaka Pelajar, 2012.

Aeni, Ani Nur. Pendidikan Karakter untuk Mahasiswa PGSD. Bandung: UPI Press, 2014.

${ }^{57}$ Lickona, Pendidikan Karakter: Panduan Lengkap Mendidik Siswa Menjadi Pintar dan Baik.., hlm.98.

200 
- - - Pendidikan Nilai, Moral, dan Krakter. Bandung: UPI Press, 2018.

Alam, Lukis. Sekolah Islam Elite, Integrasi Kurikulum dan Aspirasi Kelas Menengah Muslim di Daerah Istimewa Yogyakarta. Disertasi. Yogyakarta: UIN Sunan Kalijaga Yogyakarta, 2019.

Amin, Husna. "Aktualisasi Humanisme Religius Menuju Humanisme Spiritual Dalam Bingkai Filsafat Agama." SUBSTANTIA 15, no. $1 \quad$ (15 April 2013): 66-80. https://doi.org/10.22373/subtantia.v15i1.4885.

Anwar, Shabri Shaleh. "Tanggung Jawab Pendidikan Dalam Perspektif Psikologi Agama." Psympathic : Jurnal Ilmiah Psikologi 1, no. 1 (30 Juni 2014): 11-21. https://doi.org/10.15575/psy.v1i1.463.

Billah, Arif. "Pendidikan Karakter untuk Anak Usia Dini dalam Perspektif Islam dan Implementasinya dalam Materi Sains." Attarbiyah: Journal of Islamic Culture and Education 1, no. 2 (2016): 243-72. https://doi.org/10.18326/attarbiyah.v1i2.243-272.

Dalmeri, Dalmeri. "Pendidikan Untuk Pengembangan Karakter (Telaah Terhadap Gagasan Thomas Lickona Dalam Educating For Character)." Al-Ulum 14, no. 1 (1 Juni 2014): 269-88.

Dalyono, Bambang, dan Enny Dwi Lestariningsih. "Implementasi Penguatan Pendidikan Karakter Di Sekolah." Bangun Rekaprima: Majalah Ilmiah Pengembangan Rekayasa, Sosial Dan Humaniora 3, no. 2, Oktober (11 Oktober 2016): 33-42. https://doi.org/10.32497/bangunrekaprima.v3i2, Oktober.865.

Fakhruddin, Agus. "Urgensi Pendidikan Nilai Untuk Memecahkan Problematika Nilai Dalam Konteks Pendidikan Persekolahan." Jurnal Pendidikan Agama Islam- Ta'lim 12, no. 1 (2014): 79-96.

Farida, Siti. "Pendidikan Karakter dalam Prespektif Islam." KABILAH : Journal of Social Community 1, no. 1 (1 Juni 2016): 198-207.

Idris, Muh. "Pendidikan Karakter: Perspektif Islam Dan Thomas Lickona." Ta'dibi: Jurnal Manajemen Pendidikan Islam 7, no. 1 (3 September 2018): 77-102.

Ikhwan, Afiful. "Integrasi Pendidikan Islam (Nilai-Nilai Islami Dalam Pembelajaran)." Ta'allum: Jurnal Pendidikan Islam 2, no. 2 (1 November 2014): 179-194-194. https://doi.org/10.21274/taalum.2014.2.2.179-194. 
Imran, Ali. Metodologi Penelitian Hadist Nabi dengan Software Gawami' Al-Kalim V.4.5. Yogyakarta: Q-Media, 2019.

Juwariah dkk. Pendidikan Karakter Perspektif Pendidikam Islam. editor Sukiman. Yogyakarta: Fakultas Tarbiyah dan keguruan UIN Sunan Kalijaga, 2013.

Kuswandi, Iwan. “Tahapan Pengembangan Moral: Perspektif Barat dan Islam (Telaah Terhadap Gagasan Thomas Lickona, Lawrence Kohlberg Dan Al-Qur'an)." Ar-Risalah: Media Keislaman, Pendidikan Dan Hukum Islam 18, no. 1 (7 Mei 2020): 158-73. https://doi.org/10.29062/arrisalah.v18i1.329.

Laksana, Sigit Dwi. "Urgensi Pendidikan Karakter Bangsa di Sekolah." Muaddib: Studi Kependidikan dan Keislaman 5, no. 2 (4 April 2016): 167-84. https://doi.org/10.24269/muaddib.v5i2.67.

Lickona, Thomas. Educating For Character: Mendidik untuk Membentuk Karakter. Ed. 2. terj. Juma Abdu Wamaungo. Jakarta: Bumi Aksara, 2013.

- - - Pendidikan Karakter: Panduan Lengkap Mendidik Siswa Menjadi Pintar dan Baik. 2 ed. terj. Lita S. Bandung: Nusa Media, 2014.

Lubis, Masruroh. “Konsep Pendidikan Karakter Dalam Perspektif Islam dan Barat (Studi Komparatif Pemikiran Nashih Ulwan Dan Thomas Lickona)." Al-Fikru 12, no. 2 (24 Maret 2019). http://alfikru.staiserdanglubukpakam.ac.id/index.php/alfikru/article/view/23.

Machmud, Hadi. "Urgensi Pendidikan Moral dalam Membentuk Kepribadian Anak." Jurnal Al-Ta'dib 7, no. 2 (2014): 75-84.

Maragustam. Filsafat Pendidikan Islam Menuju Pembentukan Karakter. Yogyakarta: Pascasarjana. Fakultas Ilmu Tarbiyah dan Keguruan UIN Sunan Kalijaga, 2018.

- - - . "Paradigma Holistik-Integratif-Interkonektif Dalam Filsafat Manajemen Pendidikan Karakter." Jurnal Studi Agama dan Masyarakat 11, no. 1 (2015): 122-44. https://doi.org/10.23971/jsam.v11i1.409.

Mulyana, Rohmat. Mengartikulasikan Pendidikan Nilai. 2 ed. Bandung: al-Fabeta, 2011.

Mustari, Muhammad. Nilai Karakter: Refleksi untuk Pendidikan. 1 ed. Editor Taufik Rahman. Jakarta: Raja Grafindo Persada, 2014. 
Rochmah, Elfi Yuliani. “Mengembangkan Karakter Tanggung Jawab Pada Pembelajar (Perspektif Psikologi Barat dan Psikologi Islam)." AL-MURABBI: Jurnal Studi Kependidikan dan Keislaman 3, no. 1 (2 Juli 2016): 36-54.

Saftri, Eka, dan Ihsan Sa'dudin. "Aplikasi Integrasi Interkoneksi Keilmuan di Lembaga Pendidikan Tinggi." Tadrib 5, no. 1 (1 Juli 2019): 122-37. https://doi.org/10.19109/tadrib.v5i1.2731.

Salim, Nur Zaidi, Djam'annur, dan Aminullah. "Studi Komparasi Konsep Pendidikan Karakter Anak Menurut Al-Ghazali dan Thomas Lickona." Manarul Qur'an: Jurnal Ilmiah Studi Islam 18, no. 2 (2018): 135-53.

Sarnoto, Ahmad Zain, dan Mohammad Muhtadi. "Pendidikan Humanistik Dalam Perspektif Al-Qur'an." Alim I Journal of Islamic Education 1, no. 1 (2 April 2019): 21-46.

Sudrajat, Ajat. "Mengapa Pendidikan Karakter?" Jurnal Pendidikan Karakter 1, no. $1 \quad$ (4 Oktober 2011). https://doi.org/10.21831/jpk.v1i1.1316.

Suroso, Fuad Nashori. Agenda Psikologi Islam. 2 ed. Yogyakarta: Pustaka Pelajar, 2010.

Triwidiyastuti, dan Maragustam Siregar. "The Concept of Islamic Education Development Based on the Theory of Fitrah." Indonesian Journal of Interdisciplinary Islamic Studies (IJIIS) 2, no. 1 (2018): 31-52. https://doi.org/10.20885/ijiis.vol2.iss1.art2.

“UU_no_20_th_2003.pdf." Diakses 14 Maret 2020. https://kelembagaan.ristekdikti.go.id/wpcontent/uploads/2016/08/UU_no_20_th_2003.pdf.

Widodo, Hendro. "Pengembangan Respect Education Melalui Pendidikan Humanis Religius di Sekolah." Lentera Pendidikan: Jurnal Ilmu Tarbiyah dan Keguruan 21, no. 1 (30 Juni 2018): 11022. https://doi.org/10.24252/lp.2018v21n1i10. 